\title{
正常および病的モルモットの耳管機能における表面活性物質の役割
}

\author{
札幌医科大学耳鼻咽喉科学教室(主任:形浦昭克教授) \\ 児玉広幸, 朝 倉 光司
}

\section{ROLE OF SURFACE TENSION LOWERING SUBSTANCES IN THE FUNCTION OF NORMAL AND DISEASED EUSTACHIAN TUBES OF GUINEA PIGS}

HIROYUKI KODAMA, M.D. and KOHJI ASAKURA, M.D.

Department of Otolaryngology, Sapporo Medical College, Sapporo

To examine the role of surface tension lowering substances (STLSs), we measured changes in passive opening pressure $(\mathrm{OP})$ and closing pressure $(\mathrm{CP})$ in eustachian tubes of guinea pigs before and after washing the tubes with various solutions (saline solution, artificial pulmonary surfactant, synthetic phospholipids, and detergent)). The percent decreases in $\mathrm{OP}$ and $\mathrm{CP}$ in tubes washed with artificial surfactant were significantly higher than those washed with saline solution. Those washed with synthetic phospholipids or detergent (Triton X-100) did not differ from those washed with saline solution.

In guinea pigs with experimental otitis media produced by inoculation of formalin-killed Haemophilus influenzae into the middle ear cavity, the percent decreases in $\mathrm{OP}$ and $\mathrm{CP}$ in tubes washed with artificial pulmonary surfactant were significantly higher than in those washed with saline solution.

Artificial pulmonary surfactant was injected into the middle ear cavity of the guinea pigs with otitis media. At 5 days after inoculation, the inflammatory changes of the middle ear were much milder in animals with intratemporal application of artificial pulmonary surfactant than in those with saline application.

These results suggest the possible efficacy of treatment with artificial pulmonary surfactant for otitis media.

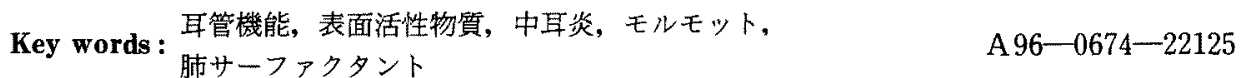

はじめに

中耳および耳管粘膜表面には，肺サーファクタント に類似した表面活性物質の存在を示唆する報告がなさ れてきた。すなわち，耳管内腔の開閉に表面張力が関 与していること文, 耳管洗浄液が肺サーファクタント と同様な表面活性作用を持ち ${ }^{2 \uparrow 6)}$, 生化学的にリン脂 質組成が類似していること年788), 組織学的には肺胞 II 型細胞に見られるのと同様なラメラ構造が耳管細胞 にも見られるこどなどである.また,耳管表面におけ る表面活性物質の減少が渗出性中耳炎の発症に関連が あることを示唆する報告もみられる(0)11).
そこで我々は，モルモットの耳管機能の指標として 受動的耳管開放圧および閉鎖圧を用い，こ机に対する 各種表面活性物質の効果を調べた。さらに，モルモッ 卜に実験的中耳炎モデルを作製し，この耳管機能に対 する表面活性物質の効果と，実際に表面活性物質を注 入した場合の中耳炎治瘜過程に対する影響を検討し た。この結果，新知見を得たので報告する。

（1）使用動物

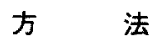

実験動物は，鼓膜所見及びプライエル反射が正常で 


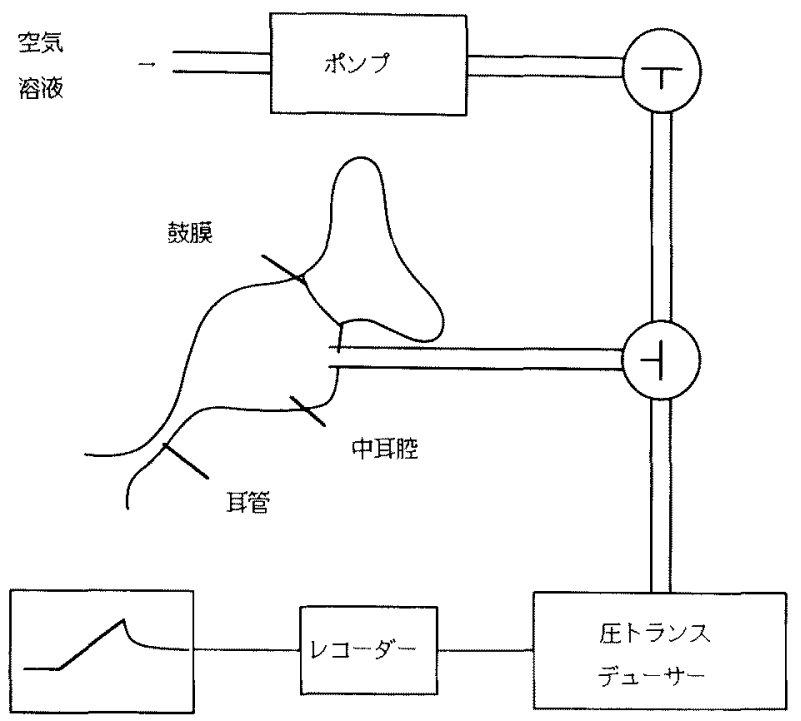

図 1 耳管開放圧および閉鎖圧测定ならびに耳管洗净方法

ある体重 $300 \mathrm{~g}$ 前後のハートレイ系モルモット（雄お よび轻）を用いた（ $\mathrm{n}=100 ）$.

（2）耳管開放压および耳管閉鎖圧の測定方法(図 1) 耳管開放圧 (opening pressure：以下 OP と略す) お よび耳管閉鎖圧 (closing pressure：以下 CP と略す)

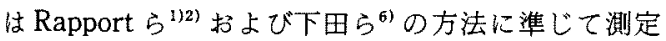
した。すなわちモルモットを断顛後，耳後部を切開し， 骨胞にドリルで小孔を開け，外径 $2 \mathrm{~mm}$ のポリエチレ ンチューブを差し込み，瞬間接着剂を用い空気漏れを 防いだ．次にこのチューブに三方活栓を接着，一方は ポンプ (Pharmasia 社製ペリスタルティックポンプ) に，もう一方は压トランスデューサー (Siment 746) に接着し，レコーダー(Cardimax FD-35S, フクダ電 子）に記録した。圧は最大 $1100 \mathrm{mmH}_{2} \mathrm{O}$ まで測定可能 であった。このため，压測定で $1100 \mathrm{mmH}_{2} \mathrm{O}$ を越える 場合は実験対象から除外した. ポンプより $0.3 \mathrm{ml} / \mathrm{min}$ の空気をチューブ内に送り込み，同時にそのチューブ 内圧を測定した。中耳腔内圧は徐々に上界し，ある点 に達すると閉鎖していた耳管は押し開かれ，耳管を通 じて上咽頭へ空気が流出する。このピーク压を OPと した。耳管開放後圧曲線は下降し，圧は急激に低下す るが○にならず，一度平衡状態となる。この時の压を CPとした。

(3) 生理的食塩水による耳管洗浄前後の耳管開放圧 および耳管閉鎖圧の測定
耳管内腔に存在すると思われる表面活性物質を除く ために，生理的食塩水（以下，生食）による洗浄を行 った。室温に保温した生食 $8 \mathrm{ml}$ を使用して耳管内腔を 洗浄後, 空気 $2 \mathrm{ml}$ を通して, 耳管内腔の生食を排除し た. 次に20分間室温保存の後, OP およびCP を測定し た. 洗浄前の剆定值を $\mathrm{OP} 0$ および $\mathrm{CP} 0$ とし, 生食 $8 \mathrm{ml}$ 洗浄後の涺定值を OP1 おょび CP1とした。

(4) 表面活性物質による耳管洗浄後の耳管開放圧お よび耳管閉鎖圧の測定

上記のように生食 $8 \mathrm{ml}$ で耳管洗浄後, 生食または各 種表面活性物質を含む溶液 $1 \mathrm{ml}$ で耳管を洗浄, 上記と 同様に空気を通し20分間後に開放圧 OP2 および閣銷 珐 CP2 測定した。

表面活性物質として使用したのは以下の5種であ る.

(1) Triton X-100 (Polyoxyetylene (10) Octylphenyl Ether) (キシダ化学)

(2)サーファクテン（東京田辺製薬）

(3) Phosphatidylethanolamine (PE) (Sigma P4264)

(4) Phosphatidylcholine (PC) (Sigma P-4139)

(5) Dipalmitoylphosphatidylcholine (DPPC) (Sigma P-5911)

(6) DPPC+Dipalmitoylphosphatidylglycerol (DPPG) (Sigma P-9789) (重量比, DPPC: 


$$
\mathrm{DPPG}=4: 1)
$$

(7) DPPC + Phosphatidylglycerol (PG) (Sigma P5531)（重量比，DPPC: $P G=4: 1$ )

以上を, $0.1 \mathrm{mg} / \mathrm{ml}, 1 \mathrm{mg} / \mathrm{ml}, 10 \mathrm{mg} / \mathrm{ml}$ の 3 種類の 濃度でそれぞれ室温下で生食中に溶解または㲘濁し た. 各りン脂質は, 生食 $1 \mathrm{ml}$ を加えた後, 10 分間の超 音波処理を行い, emulsionとしたものを使用した。こ れを耳管洗浄に用いた。

サーファクテンは, 新生児の呼吸穹迫症候群 (RDS) に対する治療の目的で，経気道的に投与されている人 エサーファクタントで, 細切牛肺の生食抽出物から粗 表面活性物質を分離，有機溶媒で脂質を抽出後，合成 脂質（パルミチン酸とトリパルミチン）を添加して表 面活性が均一になるようにした成分調整肺サーファク タントである。構成成分は，リン脂質が78〜 87\%, 脂 肪酸が 4 〜1\%,トリアシルグリセロールが $2 \sim 7 \%$, 蛋白質(肺サーファクタント・アポ蛋白質, SP-B と SP C) が0.5〜2\%含まれている ${ }^{13)}$

生食および表面活性物質を含む溶液 $1 \mathrm{ml}$ で洗浄前 後の耳管開放圧 (OP1 および OP2) および耳管閉銷圧 (CP1 および CP2) 湘定し, 洗浄前後の変化率以下 の上うに計算した。

$$
\begin{aligned}
& \text { 開放圧の変化率 }(\%)=\frac{\mathrm{OP} 1-\mathrm{OP} 2}{\mathrm{OP} 1} \times 100 \\
& \text { 閉鎖圧の変化率 }(\%)=\frac{\mathrm{CP} 1-\mathrm{CP} 2}{\mathrm{CP} 1} \times 100
\end{aligned}
$$

圧の減少は正，圧の上昇は負の値として表される。

（5）実験的中耳炎の作製方法

実験的中耳炎作製にはインフルエンザ死菌を用い た. Haemophilus influenzae non typable (ATCC33391) を液体培地（Brain Heart infusion (Difco 社) $37 \mathrm{~g} / 1$ にウサギ脱線維素血清を加えて $5 \%$ としたもの）で培序後に集菌し，ホルマリンにて不活 化処理した後、リン酸緩衝液中に浮遊させた（死菌浮 遊液：菌体濃度： $\left.1 \times 10^{9} / \mathrm{ml}\right)$ ，モルモットをネンブタ 一ル腹腔内注射にて麻酤後，26ゲージ針を用い耳後部 より経皮的に骨胞を穿刺し，ここょり上記の死菌浮遊 液約 $0.2 \mathrm{ml}$ を両側中耳腔に注入した。注入 3 日後に観 察し, 膿性耳漏や穿孔がなく, 経鼓膜的に中耳腔内に 貯留液が認められるものを対象とした。

(6) 実験的中耳炎モルモットの耳管開放圧扔よび耳 管閉鎖圧の測定

(2)と同様に, 洗浄前開放圧 $\mathrm{OP} 0$ 切上び洗浄前閉鎖圧 $\mathrm{CP} 0$ を測定し，(3) と同様に，生食 $8 \mathrm{ml}$ で耳管洗浄後内
部の貯留液を排除，空気 $2 \mathrm{ml}$ を通した後の $\mathrm{OP} 1$ およ びCP1 を測定した，次に，生食またはサーファクテン $(10 \mathrm{mg} / \mathrm{ml})$ のそれぞれ $1 \mathrm{ml}$ で耳管洗浄後，OP2 およ び CP2 を測定した。

（7）実験的中耳炎形成モルモットに対するサーファ クテンの効果

モルモット中耳腔内に, 鼓膜よりインフルエンザ死 菌浮遊液 (ATCC35056) を第 1 日および第 3 日目に注 入した，第 6 日目に膿性耳漏や穿孔がなく, 経鼓膜的 に貯留液が認められた動物を対象とし，左中耳腔内に サーファクテン $(30 \mathrm{mg} / \mathrm{ml}) 0.2 \mathrm{ml}$, 右中耳腔内に生食 $0.2 \mathrm{ml}$ をそれそれ注入し，第 9 または第11日目に断頭 屠殺した。各々の群の中耳腔内貯留液の有無を比較し, その組織像を検討した。

\section{結果}

1）正常耳管における開放圧および閉鎖圧測定の 基礎的検討

基礎実験として，死後に扝ける経時的変化，および 圧測定間隔時間の检討を行った。

1-1）死後における経時的変化の㭘討（図 2)

モルモット断頭屠殺後30分で怙, OP $515 \pm 96 \mathrm{~mm} \mathrm{H}_{2} \mathrm{O}$ 抒よび $\mathrm{CP} 371 \pm 148 \mathrm{mmH}_{2} \mathrm{O}$, 死後 3 時間経過後では $\mathrm{OP} 522 \pm 167 \mathrm{mmH}_{2} \mathrm{O}$ および $\mathrm{CP} 319 \pm 102 \mathrm{mmH}_{2} \mathrm{O} て ゙$ あり, 有意差は認められなかった。本研究では, 死後 3 時間以内にすべての実験が終了するようにした。

1-2） 圧測定問隔時間の検討（図 3)

一度圧測定した後, 30 秒後に再び測定すると $\mathrm{OP}$ は $577 \pm 170 \mathrm{mmH}_{2} \mathrm{O}$ から $313 \pm 58 \mathrm{mmH}_{2} \mathrm{O}$ 八, $\mathrm{CP}$ は $300 \pm 130 \mathrm{mmH}_{2} \mathrm{O}$ 加ら $148 \pm 61 \mathrm{mmH}_{2} \mathrm{O}$ 八著明に低下 したが，10分後 $\left(\mathrm{OP} か ゙ 531 \pm 83 \mathrm{mmH}_{2} \mathrm{O}, \mathrm{CP}\right.$ が $221 \pm$ $144 \mathrm{mmH}_{2} \mathrm{O}$ ) および20分後 (OP が $564 \pm 126 \mathrm{mmH}_{2} \mathrm{O}$, $\mathrm{CP}$ が $217 \pm 129 \mathrm{mmH}_{2} \mathrm{O}$ ) では圧測定值の回復が認め られた。このため, 本研究の圧測定間隔は20分とした。

1-3）生食に上る耳管洗浄前後の圧変化の模討 (図 4)

$\mathrm{OP} 0$ 扝よび $\mathrm{CP} 0$ を測定後生食 $8 \mathrm{ml}$ で洗浄し, OP1 および $\mathrm{CP} 1$ を測定, さらに生食 $1 \mathrm{ml}$ で洗浄し, OP2 お よびCP2 を測定した，OP0に比べ OP1 は上昇し，そ れより $\mathrm{OP} 2$ は低下する傾向がみられたが有意差はみ られなかった。また，耳管閉鎖圧の著明な変化はみら れなかった。

2) 正常モルモット耳管の表面活性物質の洗净に よる開放圧および閉鎖圧への影響（図 5，6） 


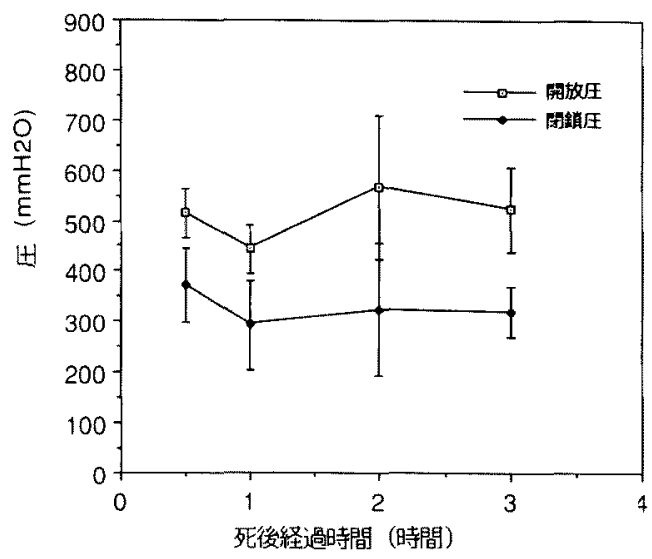

图2耳管開放圧およぴ閉鎖圧の死後に扔ける経 時的変化 $(n=4)$

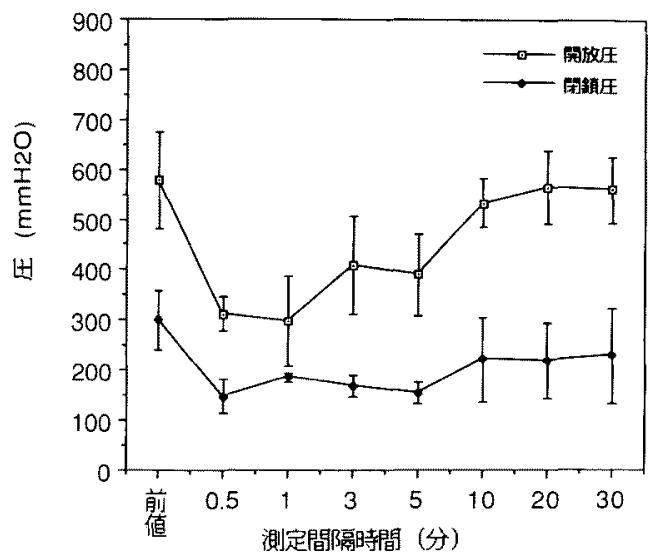

图 3 耳管開放圧方よじ閉鎖圧の測定間隔による 変化 $(n=3)$

生食及び各種表面活性物質の耳管洗浄による耳管開 放圧および閉鎖圧の変化率を検討した。サーファクテ ン $(10 \mathrm{mg} / \mathrm{ml})$ 洗浄後の耳管開放圧および閉鎖圧の変 化率は生食洗浄後に比べ, 有意に大きかった.トリト ンX $-100(1 \mathrm{mg} / \mathrm{ml})$ 洗浄後の両圧の変化率も生食洗 浄後の両圧の変化率より大きい傾向がみられたが，有 意差はなかった。各種合成リン脂質を用いた場合，そ の変化率に生食との有意差はみられなかった。

3) 実験的中耳炎形成モルモット耳管における開 放圧扝よび閉鎖圧の测定

3-1）実験的中耳炎の作製とその中耳腔粘膜組織 像 (図7)

インフルエンザ死菌注入 3 日後, 死亡したり化膿し

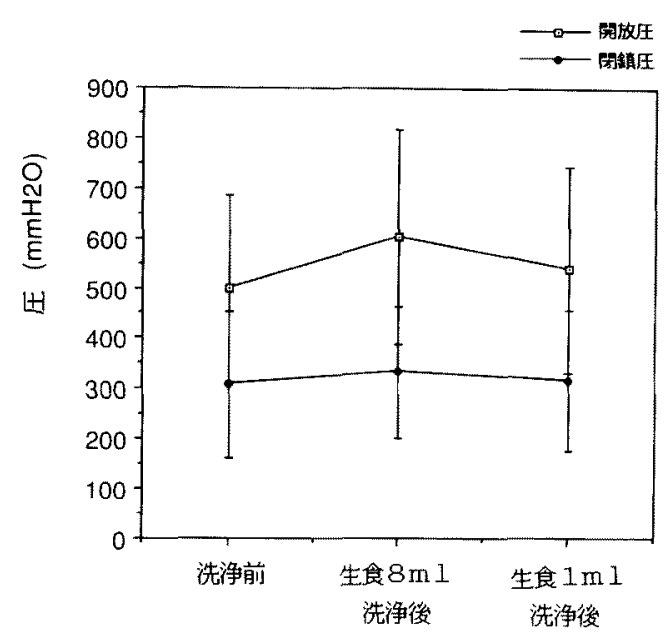

図 4 生理的食塩水による耳管洗浄前後の耳管開 放圧切よ゙閉鎖圧の変化 $(\mathrm{n}=8)$

た例を除き，両側中耳炎を形成したのは約 9 割であっ た.中耳炎形成群 (図 7-2) の中耳腔粘膜組織像を対 象群（生食注入 3 日後）(図 7-1) と比較すると, 粘 膜の浮腫, 粘膜下組織の浮腫および炎症細胞浸潤, 毛 細血管の搪張等の炎症所見がみられた。

3-2） 実験的中耳炎形成モルモット耳管と正常耳 管の耳管開放圧抢よび閉鎖圧の比較（表 1，2）

対照群に対し中耳炎形成群では，OP0およ゙ CP0 はわずかに高いが有意差はなかった. 生食 $8 \mathrm{ml}$ 洗浄後 では, 中耳炎群の OP1 および CP1 は対照群に比べて, 低い傾问がみられた。しかし，各々の圧変化率に有意 差は見られなかった。

4) 実験的中耳炎形成モルモット耳管の表面活性 物質洗浄による開放圧および閉鎖圧への影響(表 3，4） サーファクテン $(10 \mathrm{mg} / \mathrm{ml})$ 洗浄後の耳管開放圧の 圧変化および圧変化率，耳管閉鎖圧の圧変化は生食洗 浄後の値に比べ，有意に高加った。

5 ）実験的中耳炎に対する表面活性物質注入の影 響（図 8)

実験的中耳炎形成モルモットの中耳腔内に，生食あ るいはサーファクテンを注入後 3 日目では，全例の両 側に中耳貯留液がみられた。注入 5 日後の 7 例14耳を 比較した。

肉眼的に貯留液が認められたのは，生食注入側で7 耳中 5 耳で，サーファクテン注入側では 7 耳中 1 耳で あった。

その中耳腔粘膜組織像を，以下の項目で比較した。 


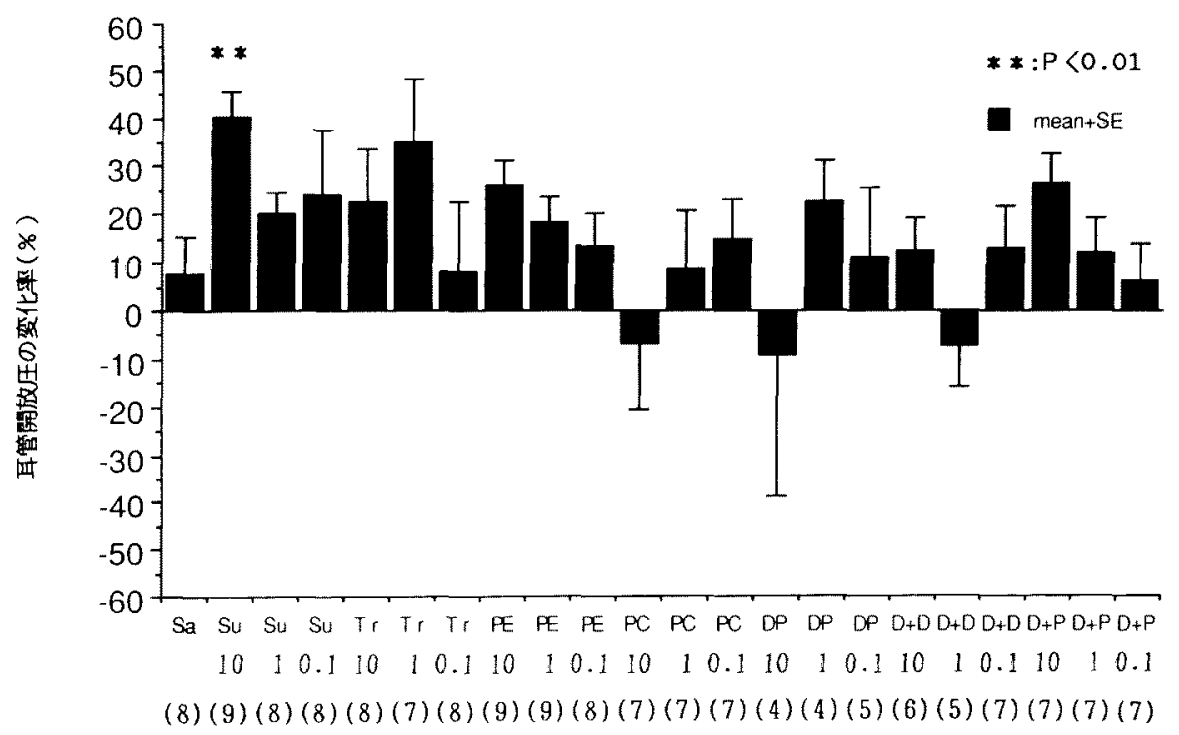

洗浄物貿

図 5 各種表面活性物質による洗浄前後の耳管開放圧の変化

$\mathrm{Sa}$ ：生理的食塩水 (対照群) Su：サーファクテン Tr: Triton X-100 PE; Phosphatidylethanolamine PC: Phosphatidylcholine DP: Dipalmitoylphosphatidylcholine $\mathrm{D}+\mathrm{D}$ : Dipalmitoylphosphatidylcholine + Dipalmitoylphosphatidylglycerol D+P: Dipalmitoylphosphatidylcholine + Dipalmytoylphosphatidylglycerol $01: 0.1 \mathrm{mg} / \mathrm{ml} 1$ : $1 \mathrm{mg} / \mathrm{ml} 10: 210 \mathrm{mg} / \mathrm{ml}$

( ) 内は例数

すなわち(1)粘膜肥厚（肥厚のないもの：一、わずかに 肥厚があるもの：士，対照群に比べて 2 倍以上の肥厚 があるもの：十，(2)炎症細胞漫潤（みられないも の：一，全視野を通してわずかにみられるもの：士， 1 視野に必ず見られるもの：十。多数見られるも $\sigma:++$. 粘膜および粘膜下組織が炎症細胞で充満し たもの: +++ ), (3)粘膜下浮腫(みられないもの: 一. わずかにみられるもの：士，明らかにみられるも の: 十, 粘膜下浮腫が十群の 2 倍以上の厚さあるも の: ++ ), (4)毛細血管拡張(見られないもの：一，わ ずかにみられるもの：士，1視野に1個以上見られる もの:十)，および(5)貯留液中細胞(これは，おもに多 核球や単核球など白血球である。みられないもの：一。 わずかにみられるもの：士，多数見られるもの：十。 中耳腔内にほほ充満してみられるもの：十+)である。

図 8 に示すようにサーファクテン注入群では生食注 入群に比べて, 炎症細胞漫潤, 粘膜下浮腫が少ないこ とが認められた。

\section{考察}

Flisberg ら”は，耳管内腔中を空気が通過するのに 要した圧力よりも生食が通過するのに要した压力の方 が高いことを報告し，空気と耳管粘膜の界面に表面張 力が関与していることを初めて推論した。このうに， 耳管を開放させるのに必要な圧を決定する主たる要素 の一つとして耳管内腔の表面張力が考えられている。

耳管内腔など空気相が液体相に接する界面には，通 常表面張力が存在する，弯曲した耳管内腔でこの表面 張力は，内腔を虚脱させるように作用する，中耳を十 分換気するのに必要な耳管開放圧は，耳管内腔の表面 張力による耳管の収縮力より大きいことが必要であ る.耳管内腔に㗢く圧Pは, LaPlace の式 $(\mathrm{P}=2 \mathrm{~T} / \mathrm{r}$, $\mathrm{T}$ : 表面張力 $\mathrm{r}$ : 耳管の半径)で計算される4).これに よれば，耳管の半径が減少し表面張力が増加するにつ れて，耳管を虚脱させる圧力が増加する，耳管にも， 肺と同様なサーファクタントが存在し，これにより耳 管内腔の表面張力が低下寸ると,耳管開放圧が低下す る. 


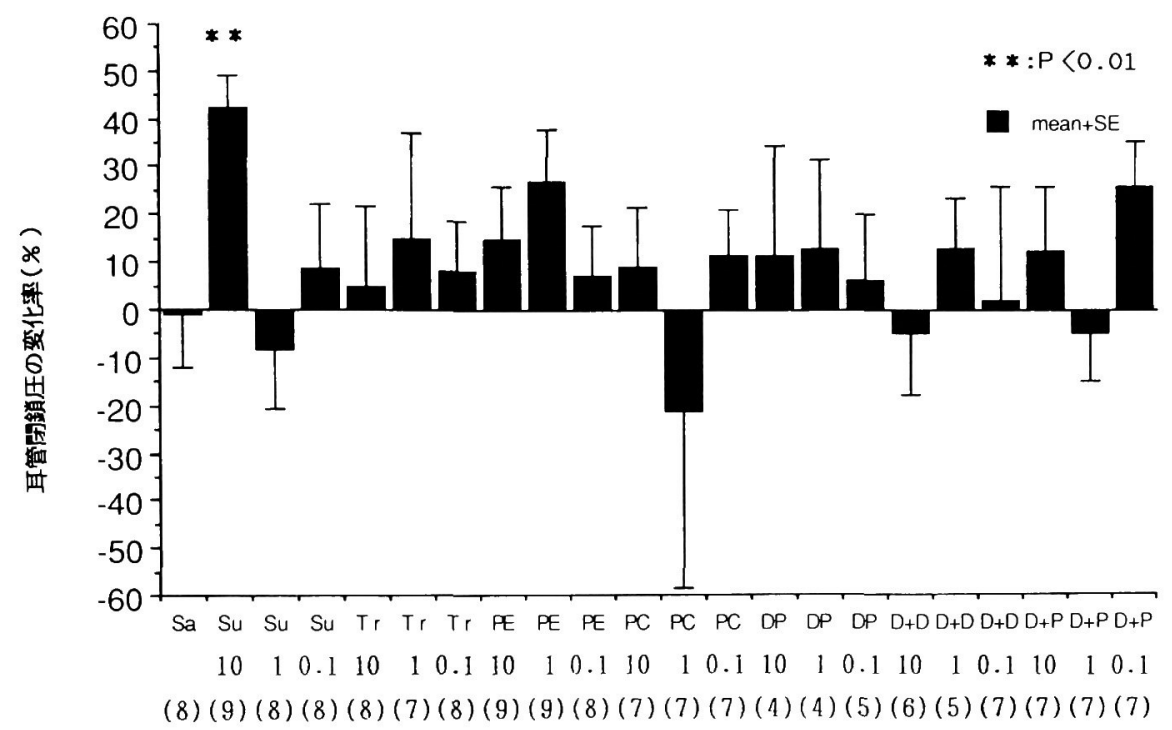

\section{洗浄物質}

図 6 各種表面活性物質による洗浄前後の耳管閉鎖圧の変化

$\mathrm{Sa}$ : 生理的食塩水 (対照群) Su：サーファクテン Tr: Trition X-100 PE; Phosphatidylethanolamine PC: Phosphatidylcholine DP: Dipalmitoylphaosphtidylcholine D+D: Dipalmitoylphosphatidylcholine + Dipalmitoylphosphatidylglycerol D $+\mathrm{P}$ : Dipalmitoylphosphatidylcholine + Dipalmitoylphosphatidylglycerol

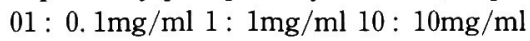
( ) 内は例数

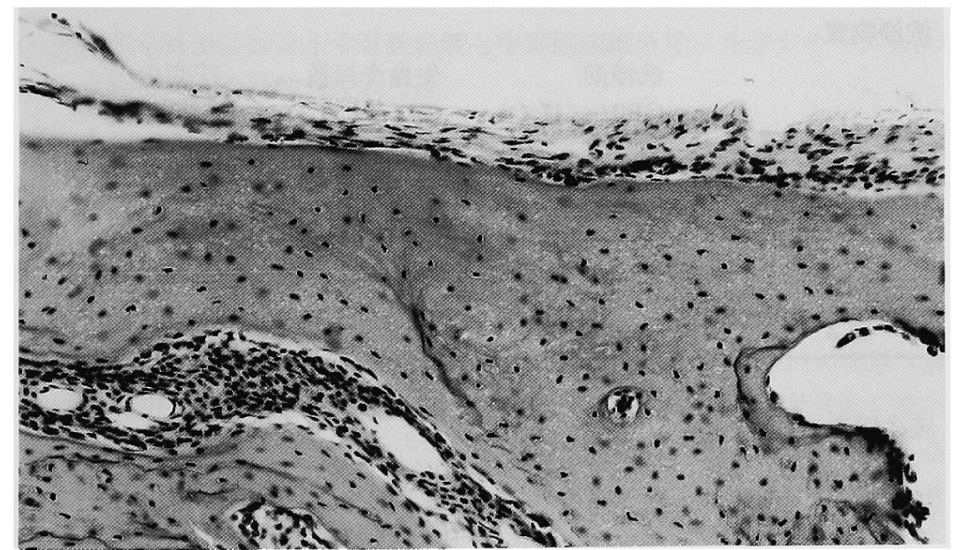

図 7-1 中耳腔粘膜組織像（対照群；生理的食塩水注入 3 日後） 


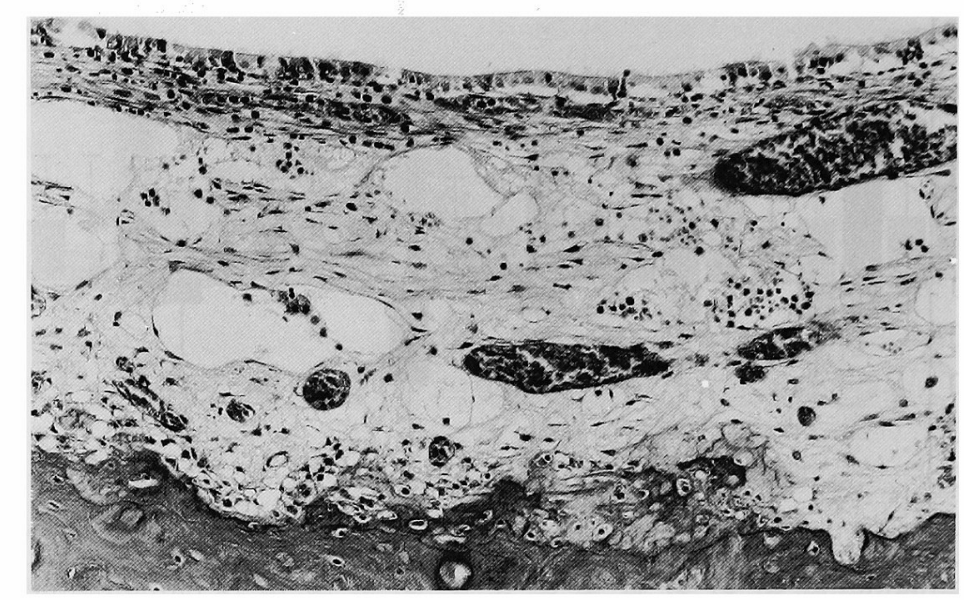

図 7-2 中耳腔粘膜組織像（インフルエンザ死菌注入 3 日後）

表 1 実験的中耳炎耳管と正常耳管の開放圧の比較

\begin{tabular}{lllllr}
\hline & & \multicolumn{4}{c}{ 耳 管 開 放 圧 } \\
& 洗浄物質 & & \multicolumn{3}{c}{} \\
& & 洗浄前 & 生食洗浄後 & \multicolumn{1}{l}{ 圧変化 } & \multicolumn{1}{c}{ 変化率 } \\
& & $\mathrm{OP0}\left(\mathrm{mm} \mathrm{H}_{2} \mathrm{O}\right)$ & $\mathrm{OP} 1\left(\mathrm{~mm} \mathrm{H}_{2} \mathrm{O}\right)$ & $\mathrm{OP} 0-\mathrm{OP} 1$ & $\mathrm{PD}(\%)$ \\
\hline 対照群 & 生食 $8 \mathrm{ml}(\mathrm{n}=8)$ & $498 \pm 187$ & $603 \pm 215$ & $-105 \pm 201$ & $-25.7 \pm 61.1$ \\
中耳炎形成群 & 生食 $8 \mathrm{ml}(\mathrm{n}=13)$ & $541 \pm 145$ & $455 \pm 187$ & $86 \pm 247$ & $2.9 \pm 48.7$ \\
\hline
\end{tabular}

表 2 実験的中耳炎耳管と正常耳管の閉鎖圧の比較

\begin{tabular}{|c|c|c|c|c|c|}
\hline & \multirow{2}{*}{ 洗浄物質 } & \multicolumn{4}{|c|}{ 耳管閉 鎖 圧 } \\
\hline & & $\begin{array}{l}\text { 洗浄前 } \\
\mathrm{CP} 0\left(\mathrm{~mm} \mathrm{H}_{2} \mathrm{O}\right)\end{array}$ & $\begin{array}{l}\text { 生食洗浄後 } \\
\mathrm{CP} 1\left(\mathrm{~mm} \mathrm{H} \mathrm{H}_{2} \mathrm{O}\right)\end{array}$ & $\begin{array}{l}\text { 圧変化 } \\
\mathrm{CP} 0-\mathrm{CP} 1\end{array}$ & $\begin{array}{l}\text { 変化率 } \\
\mathrm{PD}(\%)\end{array}$ \\
\hline 対照群 & 生食 $8 \mathrm{ml}(\mathrm{n}=8)$ & $308 \pm 145$ & $322 \pm 130$ & $-23 \pm 101$ & $-17.1 \pm 41.0$ \\
\hline 中耳炎形成群 & 生食 $8 \mathrm{ml}(\mathrm{n}=13)$ & $357 \pm 226$ & $264 \pm 120$ & $93 \pm 223$ & $9.7 \pm 39.9$ \\
\hline
\end{tabular}

表 3 実験的中耳炎耳管開放圧に対するサーファクテンの影響

\begin{tabular}{|c|c|c|c|c|c|}
\hline & & \multicolumn{4}{|c|}{ 耳 管 開 放 圧 } \\
\hline & & $\begin{array}{l}\text { 生食 } 8 \mathrm{ml} \\
\text { 洗浄後 } \\
\mathrm{OPl}\left(\mathrm{mm} \mathrm{H}_{2} \mathrm{O}\right)\end{array}$ & $\begin{array}{l}\text { サーファクテン } \\
\text { 洗浄後 } \\
\mathrm{OP} 2\left(\mathrm{~mm} \mathrm{H}_{2} \mathrm{O}\right)\end{array}$ & $\begin{array}{l}\text { 圧変化 } \\
\text { OP1-OP2 }\end{array}$ & $\begin{array}{l}\text { 変化率 } \\
\mathrm{PD}(\%)\end{array}$ \\
\hline 中耳炎形成群 & 生 食 $\quad(\mathrm{n}=7)$ & $460 \pm 249$ & $389 \pm 206$ & $71 \pm 86$ & $14.1 \pm 10.7$ \\
\hline 中耳炎形成群 & サーファクテン(n=7) & $473 \pm 97$ & $280 \pm 80$ & $195 \pm 111^{*}$ & $39.8 \pm 19.4^{* *}$ \\
\hline
\end{tabular}


表 4 実験的中耳炎耳管閉銷圧に対するサーファクテンの影響

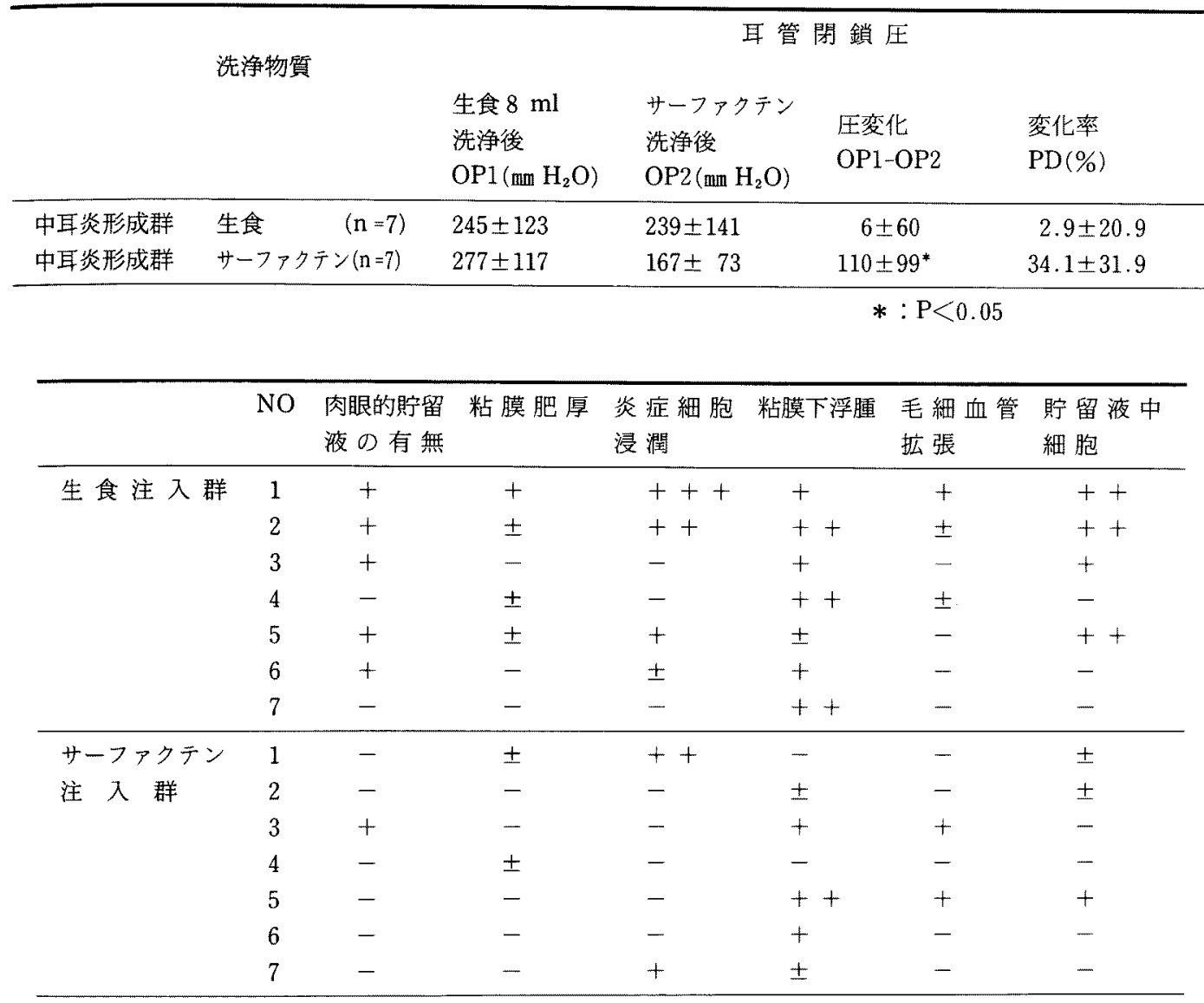

図 8 実験的中耳炎に括ける中耳腔粘液と中耳腔組織所見に及ぼすサーファクテン 中耳耳管注入の影響（注入日後）

しかし，耳管は通常閉鎖していて一時的に開口する のに対し, 肺胞は常時開口し, 内整には空気が存在す る。また，耳管粘膜表面を覆つている粘膜には多量の 蛋白質が存在し，この蛋白質が閉鎖している両耳管壁 を離れにくくする瘜着物質であるといわれている。こ のため耳管壁表面に存在するリン脂質は, 脂肪酸の疏 水性部分が内側壁に配列して耳管表面を疏水性とし, 粘液などの水溶液が付着しにくくなるように作用する と思われる。このように蛋白質などによる粘着を防ぎ， 耳管を開口し易くする作用を持つことが考えられるの で, 耳管表面に存在するりン脂質は release agent 呼ばれる81.

耳管開放圧に影響する因子としては，耳管内腔の表
面張力のほかに，耳管抢よびその周囲組織の弾性など が考えられる．特に圧測定間隔，死後硬直などによる 測定結果への影響が考えられる。本研究としては，第 一に，これらの基礎的検討を行った結果，圧測定間隔 を20分, 死後 3 時間以内に実験を終了することにし, 表面張力以外の因子を可及的に除外しょうとした。

耳管を生食 $8 \mathrm{ml}$ で洗浄すると, 耳管開放圧の明らか な上昇が観察された。これは，耳管内腔に存在方ると

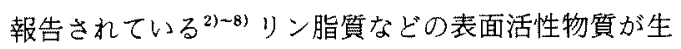
食による洗浄で失われたためと思われる.この結果は, 耳管内腔に表面活性物質が存在するという報告2や8) 支持する結果である. Rapport ら ${ }^{12)}$ は，モルモット耳 管を生食で洗浄前後の耳管開放圧扔よで閉鎖圧を測定 
し，洗浄後は両者ともに上昇することを報告した。ま た，下田ら ${ }^{6)}$ は耳管洗浄液中のリン脂質の分析を行つ て,それが肺組織の組成と類似していることを報告し, 耳管洗浄中にも肺サーファクタントと同様の物質が含 まれていることを示唆した。すなわち耳管洗浄により release agentであるリン脂質が失われ，粘膜表面の蹯 水性が減少し，耳管内腔壁が痹着しやすくなったと考 えられる. surface film や mucous blanket が洗浄によ り流されるために圧が上昇するという報告もある゙)。

生食 $8 \mathrm{ml}$ で洗浄後再び生食 $1 \mathrm{ml}$ で洗浄した場合は, $8 \mathrm{ml}$ 洗浄後の耳管開放圧と $1 \mathrm{ml}$ 洗浄後の耳管開放圧 との間に有意な上昇はなく，逆にわずかに低下した。 これは, $8 \mathrm{ml}$ 洗浄で表面活性物質は十分洗い流され，さ らに $1 \mathrm{ml} て ゙$ 洗净しても結果は変わりないことを示し ている。この結果加，耳管内腔の表面活性物質洗浄 による効果を検討する場合には，生食 $8 \mathrm{ml}$ で洗浄した 後の耳管を用いて行った。

生食洗浄前後における耳管閉鎖圧の間に有意差はな かった.

次にそ机自体で表面張力低下作用のある $\mathrm{PC}, \mathrm{PE}$ ， DPPCのリポームで耳管を洗浄したが，洗浄前後で耳 管開放圧および閉銷圧の有意な変化は見られなかっ た。

肺サーファクタント中には，DPPCを主とするリン 脂筫膜の拡散を意起させ，表面張力をすばやく低下さ せる作用を制御している成分が存在すると推定されて いる. その成分として, 不飽和型 $P^{(15) 16)}$. 酸性リン脂 質である $\mathrm{PG}^{17) 18}$ や，疎水性アポ蛋白質 (SP-B, SPC) 15/19:20) などが示されている。肺サーファクタントで は, subphase が酸性に傾くほどリン脂質,リポソーム の界面への吸着速度が早くなると報告されている 従って, 肺サーファクタント成分で, 負の荷電を与元 る酸性りン脂質のPGの役割が注目されている。本研 究では, DPPCにDPPG, PG を加元て耳管開放圧およ び閉鎖圧を測定したが，PG 添加による有意な差は見 られなかった，一方サーファクテンでは，耳管開放圧 および閉鎖圧に対し有意な隇少がみられた，合成りン 脂質とサーファクテンの耳管開放圧および閉鎖圧に対 する効果の逵いの理由として，サーファクテンにアポ 蛋白が含まれていることが考えられる、Yuら ${ }^{201}$ は, 単 分子膜の表面張力を測定した基礎的実験に扔いて, $\mathrm{DPPC} / \mathrm{PG}$ 混合物に SP-B を加えると，表面張力が低 下することを報告し，その理由として SP-B がPGの 単分子膜加らの移動を促進することを推定している。
このように, DPPC に DPPG, PG を加えるだけでは耳 管サーファクタントとしては不十分であり，柾水性ア ポ蛋白が必要であると考えられる.

リン脂質以外の界面活性剤として, 非イオン性界面 活性剤であるトリトンX-100を用いて耳管開放圧抽よ び閉鎖圧を測定したが,有意な変化は見られなかった。

本研究で使用した表面活性物資のうち, サーファク テンのみが耳管開放圧抢よび閉鎖圧に対して有意な効 果が認められた。 今回の実験は死後の状態で, 室温下 に行ったが, サーファクテンの表面吸着速度は, 12か ら $37^{\circ} \mathrm{C}$ 範囲では温度が上昇するにつれて速くなると 報告されている ${ }^{22)} の て ゙, 37^{\circ} \mathrm{C}$ 条件下では耳管開放圧 低下作用がさらに大きい可能性がある。使用したサー ファクテン濃度の妥当性については, $0.1,1$, おょび $10 \mathrm{mg} / \mathrm{ml}$ で検討したが, $10 \mathrm{mg} / \mathrm{ml}$ で, 有意な効果が見 られた。これ以上の高濃度での検討は行わなかったが, 高濃度の場合狭い耳管内腔への粘着効果の発現を恐れ たからである. $10 \mathrm{mg} / \mathrm{ml}$ で有効な結果が得られたが, 以下の実験はこの濃度を用いて行った。

実際の中耳炎に対する表面活性物質の臨床応用を考 えると表面活性物質の投与方法としては, 次の方法が 考えられる. (1)鼓膜切開後㧍よび鼓膜チューブ留置後 の貯留液のない状態における中耳腔に注入し, 耳管機 能を改善する。 (2)渗出性中耳炎の貯留液のある中耳腔 に注入し, 耳管機能を改善する.この考えに基づいて, 本研究の実験モデルを作製した。(1)のモデルとして, 実験的中耳炎形成モルモットを作製した。このモルモ ットの耳管において, 表面活性物質で洗浄した前後の 耳管開放圧と閉鎖圧を測定し，生食対照群と比較検討 した. (2)のモデルとしては, 実験的中耳炎形成モルモ ットの中耳腔内に, 経鼓膜的にサーファクテンを注入 した。実験的中耳炎の作成方法としてはインフルエン ザ死菌を注入する方法 ${ }^{23)}$ を用いた。

生食洗浄前における実験的中耳炎の耳管開放圧およ び閉鎖圧は，正常対照群に比べ有意差はなかったが， わずかに高い傾向が見られた。生食 $8 \mathrm{ml}$ 洗浄後に, 対 照群沖管開放圧ちよび閉鎖圧が高くなる傾向がある のに対し，中耳炎形成群では低くなる傾向が見られた。 実験的中耳炎形成モルモットでは，中耳および耳管内 に粘性液が貯留し，これが瘾着物質として作用するた めに,耳管開放圧抽よび閉鎖圧が上昇した状態にある。 生食洗浄によって,この粘性貯留液が洗い流されたた めに開放圧および閉鎖圧が低下したと考えられる。こ れに対し, 対照群では生食洗浄により表面活性物質が 
失われるために耳管開放区および閉鎖圧は上昇したと 考えられる。中耳炎時における耳管開放圧については 過去に幾つかの報告 ${ }^{24) 25) 26)}$ がみられる。人の㑢出性中 耳炎の通気圧は正常範囲が大多数とされている ${ }^{24) 251}$.

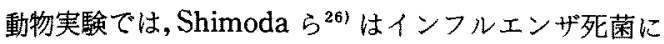
よる渗出性中耳炎モデルを作製し，正常耳管では生食 洗净後耳管開放圧が上昇したのに対し，中耳炎耳管で は耳管開放圧は変化しなかったと報告している，化膿 性中耳炎による実験で, White ${ }^{27)}$ は肺炎球菌により 中耳炎を作製し，洗浄前の耳管開放圧は対象群上りも 低値であったと報告した。この理由として彼らは，中 耳炎急性期に扔いては，膿性貯留液が耳管からの非泄 されることにより，耳管が開放されているためと推測 している. 本実験モデルでは，化膿性中耳炎は除外し て扔り，鼓室内に滲出性貯留液が認められた動物を選 んだため，このような現象は見られなかったものと考 えられる。

サーファクテンで耳管洗浄を行うと, 耳管開放圧ち よび閉鎖圧は有意に低下することが認められた。実験 的中耳炎形成モルモットの耳管においても，サーファ クテンを補充することによる効果が認められた。 White ${ }^{27}$ は化膿性中耳炎形成王ルモットに扔いて, 肺サーファクタント(プタ肺洗浄液のリン脂質分画を 調製したもので，99\%のリン脂貿と $1 \%$ の蛋白質が含 まれる) 洗浄液に，対象群に見られたのと同等の耳管 開放圧低下が見られたと報告している。今回の奏験で は, 中耳炎形成群の耳管開放圧および閉鎖圧は, 正常 対照群よりやや高い圧であったが, 生食洗浄によって やや低下し，サーファクテン洗浄によりさらに低下し た.この結果加ら, 鼓膜切開後生食等で鼓室内を洗浄 し，貯留液を十分除去した後にサーファクテンを注入 する方法が耳管機能回復による中耳炎治療法として示 唆される。

インフルエンザ死菌注入による実験的中耳炎形成モ ルモットのサーファクテン注入群において, 中耳貯留 液はほとんど見られなかった。また対照群（生食注入 群)に比べて，サーファクテン注入群では中耳粘膜に おける炎症所見は少ない傾向であった。サーファクテ ン注入により，中耳腔内の炎症性物質が中耳腔から耳 管人排泄されたためと考えられる。肉眼的に中耳貯留 液が消失し，中耳腔内に炎症細胞が見られなくなった 後も,粘膜の炎症所見が残存している例が認められた。 この結果から，中耳貯留液が排泄された後，粘膜の炎 症が消退すると考えられる，すなわち，サーファクテ
ン注入によって, 中耳内腔の炎症性物質が排泄され易 くなったと考えられる。耳管開放压抽よび閉鎖圧の実 験系では,圧平衡作用について主に見たものであった。 耳管には，压平衡作用と並んで粘液䋐毛輸送系がある といわれているが，中耳腔へのサーファクテン注入に よるこの輸送系に対する影響の検討も必要であろう。

$$
\text { まとめ }
$$

1）今回我々はモルモット取管を用い耳管開放圧お よび閉鎖圧を測定した。死後 3 時間以内および測定間 隔を20分以上とした場合，前㑬との有意差はみられな かった。

2) 耳管を生食 $8 \mathrm{ml}$ で洗浄すると，耳管開放圧は上 昇する傾向がみられた，耳管開鎖圧に変化は見られな かった。

3）表面活性物質として，合成リン脂質，蛋白質を 含む人工肺サーファクタント(サーファクテン)。合成 表面活性物質で耳管を洗浄し，その効果を検討した。 サーファクテンで耳管を洗浄した後，耳管開放圧およ び閉鎖圧は有意に低下したが他の表面活性物質で耳管 洗浄した時, 有意差はみられなかった。

4）インフルエンザ死菌をモルモット中耳腔内に注 入し，実験的中耳炎を作成した。

5）中耳炎耳管を生理的食塩水 $8 \mathrm{ml}$ で洗浄すると 耳管開放圧及び閉鎖圧は低下する傾向がみられた。

6）中耳炎耳管をサーファクテンで洗浄すると，耳 管開放圧および閉鎖圧の有意な低下が見られた。

7）実験的中耳炎形成モルモットの中耳腔内にサー ファクテンを注入後 5 日目の組織像を検討した。対照 群に比べて, 中耳貯留液はほとんど認められず, 組織 像では炎症所見が少なかった。

以上の結果，サーファクタントの中耳腔内注入が耳 管機能を好転し，中耳の炎症を消退せしめると考えら れるので, 滲出性中耳炎の治療方法として有用である ことが示唆された。

\section{参考文献}

1) Flisberg $K$, Ingelstedt $S$, Ortegren $U$ : The valve and "locking" mechanisms of the eustachian tube. Acta Otolaryngol Suppl 182: 57-68, 1963.

2) Brookler KH, Birken EA : Surfase tension lowering substance of the eustachian tube. Laryngoscope 81 : 1671-1673, 1971.

3) Birken EA, Brookler KH : Surface tension lowering 
substance of the canine eustachian tube. Ann Otol 81 : 268-271, 1972.

4) Hagan WE: The mucous blanket of the eustachian tube: a morphologic and surface property demonstration. ORL $84: 242-268,1977$.

5) Hagan WE: Surface tension lowering substance in eustachian tube function. Laryngoscope 87 : 10331045, 1977.

6）下田和夫，森本餐治：プタ耳管に抢ける Surface Tension Lowering Substance $の$ 検討. 札幌医詰 53: 353-365, 1986

7) Wheeler SL, Pool GL, Lumb RH : Rat eustachian tube synthesizes disaturated phosphatidylcholine. BBA 794: 348-349, 1984.

8) Hills BA: Analysis of eustachian surfactant and its function as a release agent. Arch Otolaryngol $110: 3-9,1984$

9) Tsuruhara K, Morii S, Kumazawa T: Ultracytochemical demonstration of phospholipids in the surface layer of the guinea pig eustachian tube. Acta Otolaryngol 108: 434-441, 1989.

10) Grace A, Kwok P, Hawke $M$ : Surfactant in middle ear effusions. Otolaryngol Head Neck Surg 96 : 336-340, 1987.

11) Svane-Knudsen $V$, Larsen HF, Brask $T$ : Secretory otitis media-A question of surface activity in the eustachian tube? Acta Otolaryngol 105: 114-119, 1988.

12) Rapport PN, Lim DJ, Weiss HS : Surface-active agent in eustachian tube function. Arch Otolaryngol 101: 305-311, 1975.

13）小川雄之亮，金子広司，板倉敬乃，中村利彦、大浜 洋一他：呼吸窮迫症候群の肺サーファクタント療法. 小坚科臨床 42:733-741，1989.

14）矢部利江：小児と成人中耳貯留波の生化学的特徵 第 一報 脂質成分.日耳鼻 $94: 516-524 ， 1991$.

15）秋野豊明：肺の脂質代謝と surfactant，望月正司他 編: 臨床生理学シリーズ(2) 肺. 南江堂, 東京, 1989, 2-16頁.

16) Egberts J, Sloot H, Mazure A: Minimal surface tension, squeeze-out and transition temperatures of binary mixtures of dipalmitoylphosphatidylcholine and unsaturated phospholipids. BBA 1002: 109-
$113,1989$.

17) Hallman $M$, Gluck $L$ : Phosphatidylglycerol in lung surfactant. III. Possible modifier of surfactant function. J Lipid Res $17: 257-262,1976$.

18) Cernansky G, Liau DF, Hashim SA et al: Estimation of phosphatidylglycerol in gluids containing pulmonary surfactant. J Lipid Res 21 : 1128-1131, 1980

19) King RJ, Macbeth MC: Physicochemical properties of dipalmitoyl phosphatidylcholine after interaction with an apolipoprotein of pulmonary surfactant. BBA 557: 86-101, 1976.

20) $\mathrm{Yu} \mathrm{SH}$, Possmayer F: Role of bovine pulmonary surfactant-associated proteins in the surface-active property of phospholipid mixtures. BBA 1046: 233-241, 1990.

21）田中勇次, 武井恒知, 金沢洋作, 木内詮、藤原 哲郎：人工肺 surfactant の物理化学的ならびに生理 学的性質、日界面医会誌 $13: 111-120,1982$.

22）小林 勉: Subphase の影響、吉田清一他編; 肺表面 活性物資の現在. 真興交易医書出版部，東京，1990， 7-15頁.

23) DeMaria TF, Briggs BR, Lim DJ et al : Experimental otitis media with effusion following middle ear inoculation of nonviable $\mathrm{H}$ influenzae. Ann Otol Rhinol Laryngol $93: 52-56,1984$.

24）高橋晴雄，林 正彦，倉田響介，本庄 巌：滲出性中 耳炎の耳管機能。耳鼻臨床 79:1589-1597，1986.

25）湯浅 涼，高良 稔：耳管の物理的性質の解析. 日耳 鼻74：749-754，1971.

26) Shimoda K, Shido F, Morimoto $K$ et al : A role of surface tension lowering substance in eustachian tube function. Auris Nasus Larynx 12 (Suppl 1) : 132-134, 1985.

27) White $P$, Hermansson A, Svinhufvud $M$ : Surfactant and isoprenaline effect on eustachian tube opening in rats with acute otitis media. Am J Otolaryngol $11: 389-392,1990$.

（1992年11月30日受稿 1993年 2 月 4日受理 急載）

別刷請求先 $\mathbf{T} 060$ 札幌市中央区南 1 条西16丁目 札幌医科大学耳鼻咽喹科学教室 呪玉宏幸 


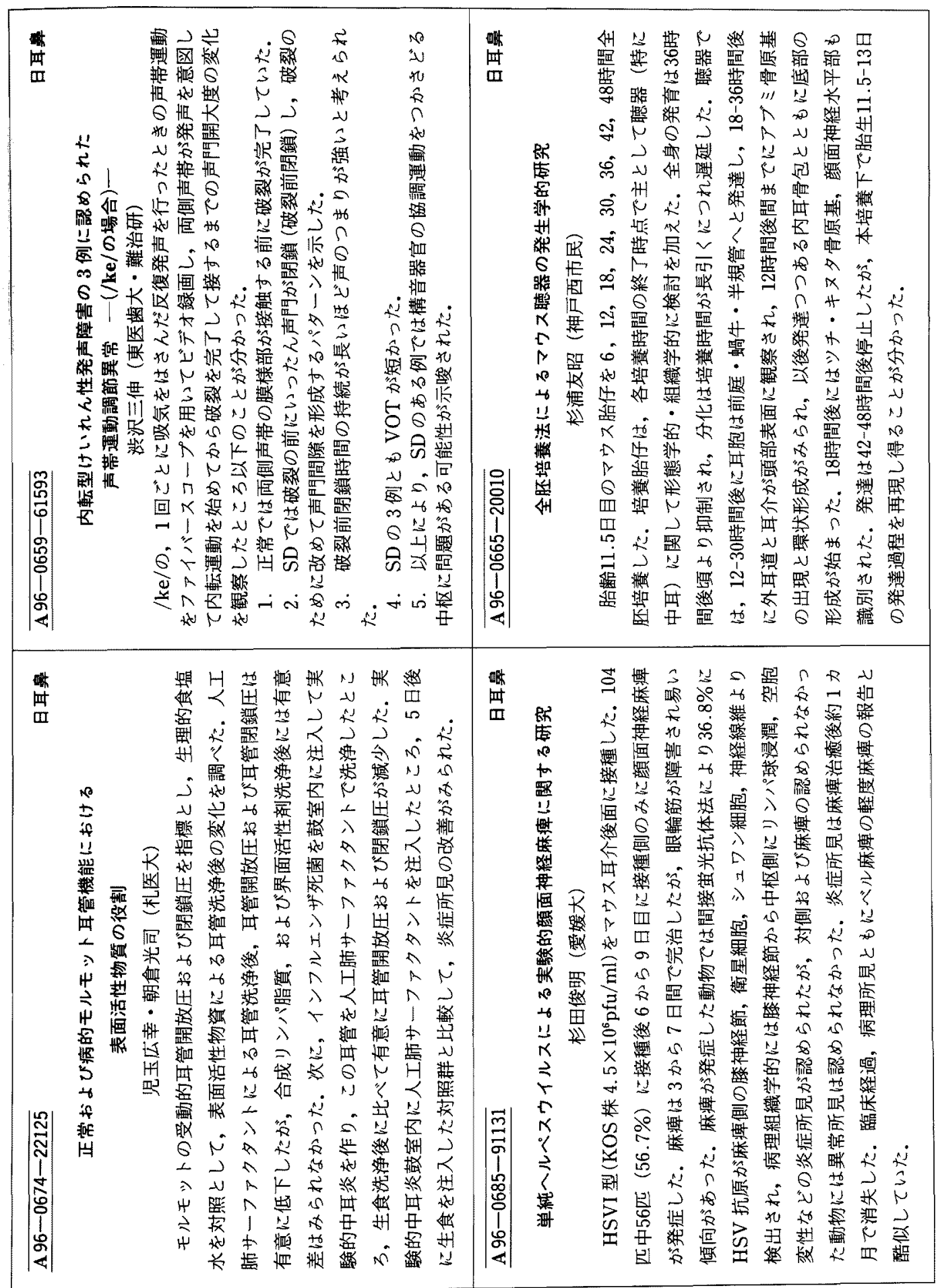

